\author{
Ryszard BARTNIK ${ }^{1}$ \\ Zbigniew BURYN ${ }^{2}$ \\ Anna HNYDIUK-STEFAN ${ }^{3}$
}

\title{
WHICH POWER TECHNOLOGIES ARE WORTH CONSIDERING AS AN INVESTMENT?
}

\begin{abstract}
The analysis in this paper involves the issues of the specific cost of electric power generation in the particular technologies applied in its production. Therefore, the analysis involves all accessible technologies in power engineering (except hydroelectric power stations): coal-fired power plants applying conventional combustion and CCS (Carbon Capture and Storage) technology in oxy-combustion, nuclear power plants, combined cycle power plants - CCPP, dual-fuel combined cycle power plants - DFCC, wind farms, photovoltaics power plants. The article presents from the economic perspective, that the most beneficial technology is the one in which the cost of power generation is the lowest. It is relative to: specific cost of investment, internal electric load of the power plant, its annual operating time, fuel prices and their variability in time, ratio of the chemical energy of the fuel in its total annual use, for which the purchase of additional $\mathrm{CO} 2$ allowances and tariff rates on the use of the environment is not required. The calculations apply the methodology and mathematical modeling of the specific cost of electric power generation valuation in continuous time. The use of continuous time approach provides an options for the analysis of various scenarios regarding variability of energy carriers in time. Moreover, such approach can apply differential calculus for the calculation of the specific cost of electricity production. The analysis of sensitivity of the cost incurred in such production can aid in the assessment of the variability of energy carrier prices in the function of the parameters which influence the overall cost.
\end{abstract}

Keywords: power technologies, specific cost of electricity production, CCS, CCPP, DFCC

\section{INTRODUCTION}

A decision regarding an investment in power engineering needs to be based on information giving answers to a few questions. What are the suitable technologies to guarantee Poland's security of energy supply, including security and continuity of electricity supply? What is the influence of the prices of energy carriers and what relations between them need to be maintained to maintain a target value of an adopted criterion in the search for an optimum investment strategy? The above questions are relevant with regard to the economic efficiency of technologies applied in power engineering. It seems quite clear that profit on an investment should be as high as possible, the cost of electricity produc-

\footnotetext{
${ }^{1}$ Prof. Ryszard Bartnik, DSc, PhD,Eng., Opole University of Technology, Faculty of Production Engineering and Logistics, Department of Power Engineering Management.

${ }^{2}$ Zbigniew Buryn, PhD, Eng., Opole University of Technology, Faculty of Production Engineering and Logistics, Department of Power Engineering Management.

${ }^{3}$ Anna Hnydiuk-Stefan, PhD,Eng., Opole University of Technology, Faculty of Production Engineering and Logistics, Department of Power Engineering Management.
} 
tion should be low whereas the condition of stability and security of power supply is fulfilled.

The aim of this paper is to present analysis which involves the issues of the specific cost of electric power generation in the particular technologies applied in its production. Therefore, the analysis involves all accessible technologies in power engineering (except hydroelectric power stations):

- coal-fired power plants applying conventional combustion and CCS (Carbon Capture and Storage) technology in oxy-combustion ${ }^{4}$ (Fig. 1),

- nuclear power plants (Fig. 1),

- combined cycle power plants - CCPP (Fig. 2),

- dual-fuel combined cycle power plants - DFCC (Figs. 3\&4),

- wind farms,

- photovoltaics power plants.

The calculations apply the methodology and mathematical modeling of the specific cost of electric power generation valuation in continuous time (formula (1) $)^{5}$. The use of continuous time approach provides an options for the analysis of various scenarios regarding variability of energy carriers in time. Moreover, such approach can apply differential calculus for the calculation of the specific cost of electricity production. The analysis of sensitivity of the cost incurred in such production can aid in the assessment of the variability of energy carrier prices in the function of the parameters which influence the overall cost.

\section{APPLICATION OF A MATHEMATICAL MODEL IN SEARCH FOR AN OP- TIMUM INVESTMENT STRATEGY OF INVESTMENT IN ELECTRICITY SOURCES}

The mean specific cost of electricity generation is expressed by the formula ${ }^{5}$ :

$$
\begin{aligned}
k_{e l, a v} & =\left\{\left(1+x_{s w, m, w a s}\right) \frac{e_{f u e l}^{t=0}}{a_{f u e l}-r}\left[\mathrm{e}^{\left(a_{\text {futell }}-r\right) T}-1\right]+\frac{\rho_{\mathrm{CO}_{2}} p_{C O_{2}}^{t=0}}{a_{C O_{2}}-r}\left[\mathrm{e}^{\left(a_{C O_{2}}-r\right) T}-1\right]+\frac{\rho_{C O} p_{C O}^{t=0}}{a_{C O}-r}\left[\mathrm{e}^{\left(a_{C O}-r\right) T}-1\right]+\right. \\
& +\frac{\rho_{N O_{X}} p_{N O_{X}}^{t=0}}{a_{N O_{X}}-r}\left[\mathrm{e}^{\left(a_{N O_{X}}-r\right) T}-1\right]+\frac{\rho_{S_{2}} p_{S O_{2}}^{t=0}}{a_{S O_{2}}-r}\left[\mathrm{e}^{\left(a_{S O_{2}}-r\right) T}-1\right]+ \\
& +\frac{\rho_{\text {dust }} p_{d u s t}^{t=0}}{a_{d u s t}-r}\left[\mathrm{e}^{\left(a_{\text {dust }}-r\right) T}-1\right]+(1-u) \frac{\rho_{C O_{2}} e_{C O_{2}}^{t=0}}{b_{C O_{2}}-r}\left[\mathrm{e}^{\left(b_{C O_{2}}-r\right) T}-1\right]+ \\
& \left.+\frac{\eta_{e l}}{r t_{A}}\left[\left(1+x_{\text {sal, t,ins }}\right) i\left(1-\mathrm{e}^{-r T}\right) \delta_{\text {serv }}+r i z\left(\frac{1-\mathrm{e}^{-r T}}{T}+1\right)\right]\right\} \frac{r}{\eta_{e l}\left(1-\varepsilon_{e l}\right)\left(1-\mathrm{e}^{-r T}\right)} \rightarrow \text { min. }
\end{aligned}
$$

\footnotetext{
${ }^{4}$ Hnydiuk-Stefan A., Analysis of the parameters of power plants operating in oxy-fuel combustion, Ph.D. thesis, Opole University of Technology 2014 [in Polish]

${ }^{5}$ Bartnik R., Bartnik B., Hnydiuk-Stefan A., Optimum Investment Strategy in the Power Industry, Springer, New York 2016
} 
where:

$a_{e l}, a_{\text {fuel }}, a_{\mathrm{CO}_{2}}, a_{\mathrm{CO}}, a_{\mathrm{SO}_{2}}, a_{\mathrm{NO}_{X}}, a_{d u s t}, b_{\mathrm{CO}_{2}}-$ controls ${ }^{6,7}$,

$\delta_{\text {serv }}$ - annual rate of constant cost regardless of the value of investment (cost of maintenance of overhaul of equipment),

$\varepsilon_{e l}$ - internal electric load of the power plant (its value is relative to the technology applied in electric power generation),

$\eta_{e l}$ - gross electric power efficiency (its value is relative to the technology applied in the electric power generation),

$u$ - ratio of the chemical energy of the fuel in its total annual use for which the purchase of additional $\mathrm{CO}_{2}$ allowances is not required,

$p_{\mathrm{CO}_{2}}, p_{\mathrm{CO}}, p_{\mathrm{NO}_{x}} p_{\mathrm{SO}_{2}}, p_{\text {dust }}-$ specific rates per emissions of $\mathrm{CO}_{2}, \mathrm{CO}, \mathrm{NO}_{x}, \mathrm{SO}_{2}$, particulate matter, PLN/kg,

$\rho_{\mathrm{CO}_{2}}, \rho_{\mathrm{CO}}, \rho_{\mathrm{NO}_{x}}, \rho_{\mathrm{SO}_{2}}, \rho_{\text {dust }}-$ emission of $\mathrm{CO}_{2}, \mathrm{CO}, \mathrm{NO}_{\mathrm{x}}, \mathrm{SO}_{2}$, per unit of the chemical energy of fuel, $\mathrm{kg} / \mathrm{GJ}$ (relative to the type of fuel).

$r$ - discount rate,

$t_{A}-$ annual operating time,

$T$ - calculated exploitation period of a power plant expressed in years (depreciation rate),

$x_{s w, m \text {,was }}-$ coefficient used to account for the cost of supplementing water, use of auxiliary materials and waste disposal,

$x_{\text {sal, }, \text { ins }}-$ coefficient used to account for the cost of remuneration, taxes, insurance, etc.

$z$ - coefficient expressing immobilization of capital ${ }^{6,7}$.

From the economic perspective, the most beneficial technology is the one in which the cost of power generation $k_{e l, a v}$ is the lowest. It is relative to: specific cost of investment $i$, internal electric load of the power plant $\varepsilon_{e l}$, its annual operating time $t_{A}$, fuel prices and their variability in time, ratio $u$ of the chemical energy of the fuel in its total annual use, for which the purchase of additional $\mathrm{CO} 2$ allowances and tariff rates on the use of the environment is not required.

\section{DISCUSSION AND ANALYSIS OF EXEMPLARY RESULTS}

Figs. 5-14 present the results of calculations regarding specific cost of electric power production $k_{e l}$ in the specific technologies. Figs. 1-4 contain the energy balances corresponding to them. Table 1 contains the input data used in these calculations. Figs. 5-14 also show how the value of $k_{e l}$ is affected by the variability in the fuel prices $e_{\text {fuel }}$, investment $J$ and internal electric load of the power plant $\varepsilon_{e l}$. The variability of these values was assumed to vary in the range of $20 \%$ from the base values (Tables 1 and 2) The presented results deal with both the payback period of the investment as well as the period which follows it. The reduced prices which correspond to the base ones assume the value of 1 on the $\mathrm{X}$ axis in Figs. 5-14.

\footnotetext{
${ }^{6}$ Bartnik R., Bartnik B., Hnydiuk-Stefan A., Optimum Investment Strategy in the Power Industry, Springer, New York 2016.

${ }^{7}$ Bartnik R., Bartnik B., Economic calculations in power engineering, WNT, Warszawa 2014 [in Polish].
} 


\subsection{Power units in the conventional and $C C S$ technologies and nuclear installation}

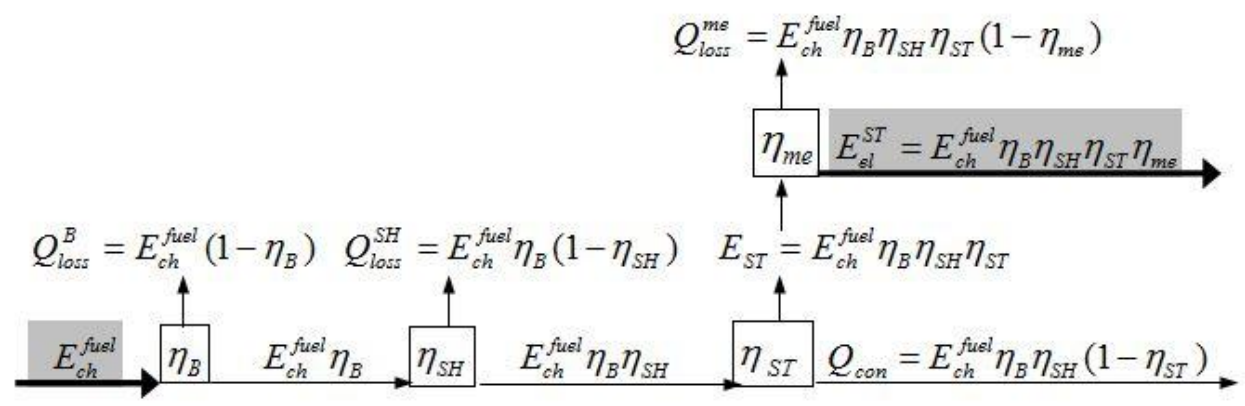

Fig. 1. Energy balance in a conventional technology, CCS technology and a nuclear installation (for the case of nuclear power plant, a nuclear reactor and steam generator is used in the place of a boiler).

Source: own calculations

The gross efficiency of electric power generation in units with sub- and supercritical steam parameters is expressed by the formula (for the case of the nuclear power plant, the efficiency of the boiler $\eta_{B}$ is expressed by the efficiency of the reactor and steam generator):

$$
\eta_{e l}=\frac{E_{e l}^{S T}}{E_{c h}^{f u e l}}=\eta_{B} \eta_{S H} \eta_{S T} \eta_{m e}
$$

At present, this efficiency can be as high as above 50\% (whereas for nuclear power plants around $40 \%$ ).

The net efficiency of electric power generation is expressed by the formula:

$$
\eta_{e l, n e t}=\eta_{e l}\left(1-\varepsilon_{e l}\right)
$$

The net efficiency of the units operating in the particular technologies are functions of their internal electric load $\varepsilon_{e l}$. By substitution of formulae (2), (4)-(6) instead of (1), we can analyze the effect of the efficiency of the equipment applied in the analyzed technologies on the value of $k_{e l, a v}$. For the case of gas and steam units, it is then necessary to account for the annual use of the chemical energy of gas in the gas turbogenerator with the capacity of $N_{e l}^{S T}$ an efficiency of $\eta_{S T}$ equal to $E_{c h, A}^{g}=\left(N_{e l}^{G T} \tau_{A}\right) / \eta_{G T}$, as well as account for the production electric power in them. In the search for the minimum of the cost $k_{e l, a v}$, optimization should involve the ratio of the chemical energy of the gas in the chemical 
energy of the coal combustion in the power plant in equations (5) and (6), i.e. $q_{p a r}=E_{c h, A}^{\text {gas }} / E_{c h, A}^{c o a l}$ and $q_{s e r}=E_{c h, A}^{\text {gas }} / E_{c h, A}^{c o a l}$.

\subsection{Combined cycle units}

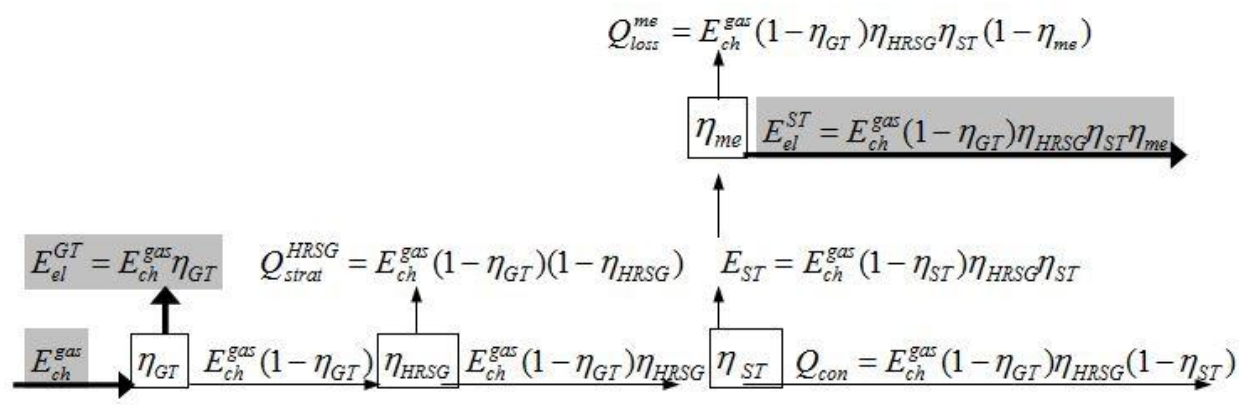

Fig. 2. Energy balance of a combined cycle power unit.

Source: own calculations

The gross efficiency of electric power generation in a combined cycle unit is expressed with a formula:

$$
\eta_{e l}=\frac{E_{e l}^{G T}+E_{e l}^{S T}}{E_{c h}^{g a s}}=\eta_{G T}+\left(1-\eta_{G T}\right) \eta_{H R S G} \eta_{S T} \eta_{m e}
$$

At present this efficiency can be as high as above $60 \%$ (with a note that the steam pressure in combined cycle power unit which secures its highest efficiency is two times lower from the value of the critical pressure in it ${ }^{8}$ ).

\footnotetext{
${ }^{8}$ Bartnik R., Combined Cycle Power Plants. Thermal and economic effectiveness, (Wydawnictwa NaukowoTechniczne WNT), Warszawa 2009 (reprint 2012).
} 


\subsection{Dual-fuel combined cycle unit in a parallel system}
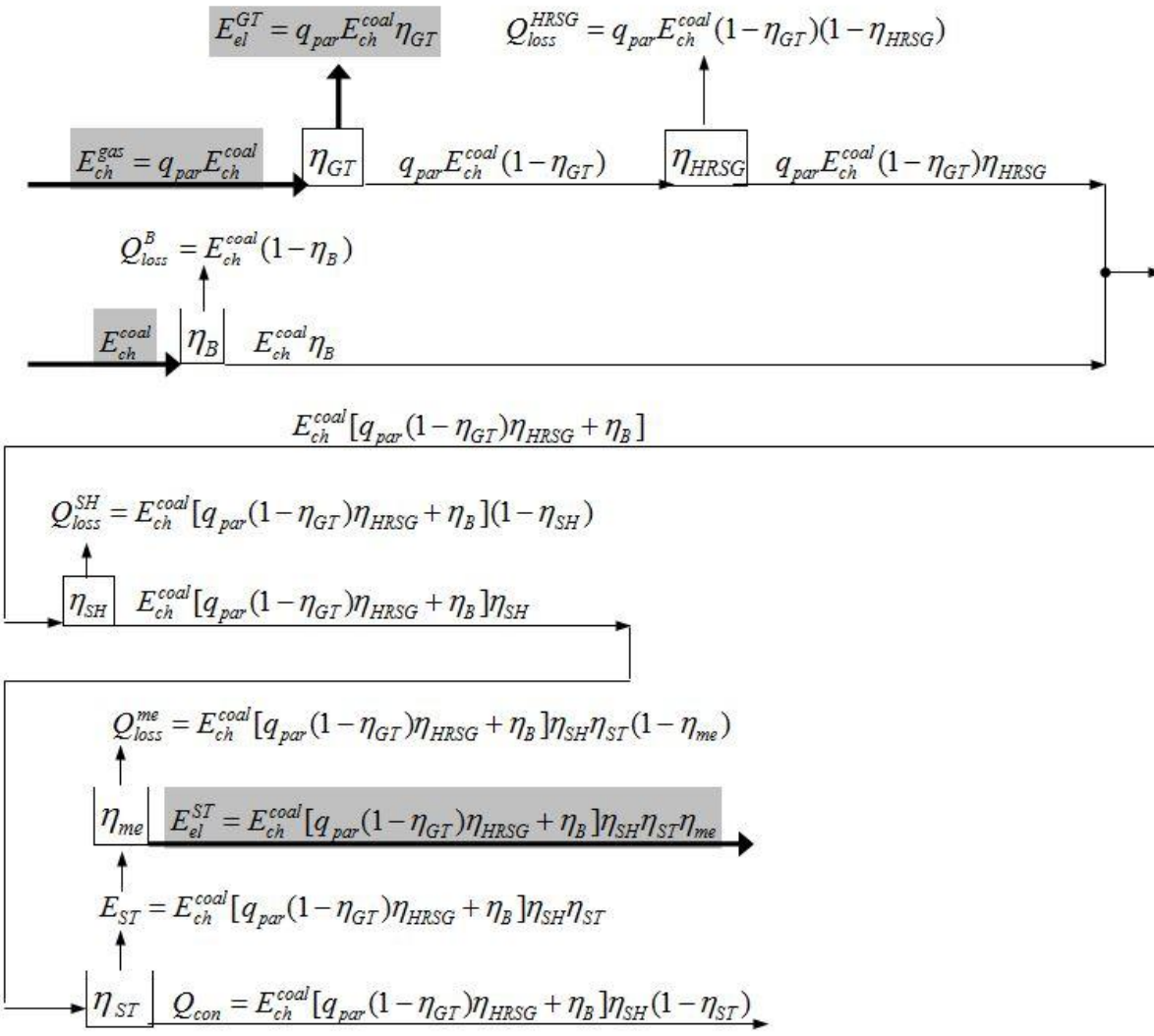

Fig. 3. Energy balance of dual-fuel combined cycle unit in a parallel system Source: own calculations.

The gross efficiency of electric power generation in a dual-fuel combined cycle unit in a parallel system is expressed by the formula (this efficiency can be as high as 50\% ${ }^{9}$ ):

$$
\eta_{e l}=\frac{E_{e l}^{G T}+E_{e l}^{S T}}{E_{c h}^{g a s}+E_{c h}^{c o a l}}=\frac{q_{p a r} \eta_{G T}+\left[q_{p a r}\left(1-\eta_{G T}\right) \eta_{S H}+\eta_{B}\right] \eta_{S H} \eta_{S T} \eta_{m e}}{1+q_{p a r}}
$$

\footnotetext{
${ }^{9}$ Bartnik R., Combined Cycle Power Plants. Thermal and economic effectiveness, (Wydawnictwa NaukowoTechniczne WNT), Warszawa 2009 (reprint 2012).
} 


\subsection{Dual-fuel combined cycle unit with in-series configuration}

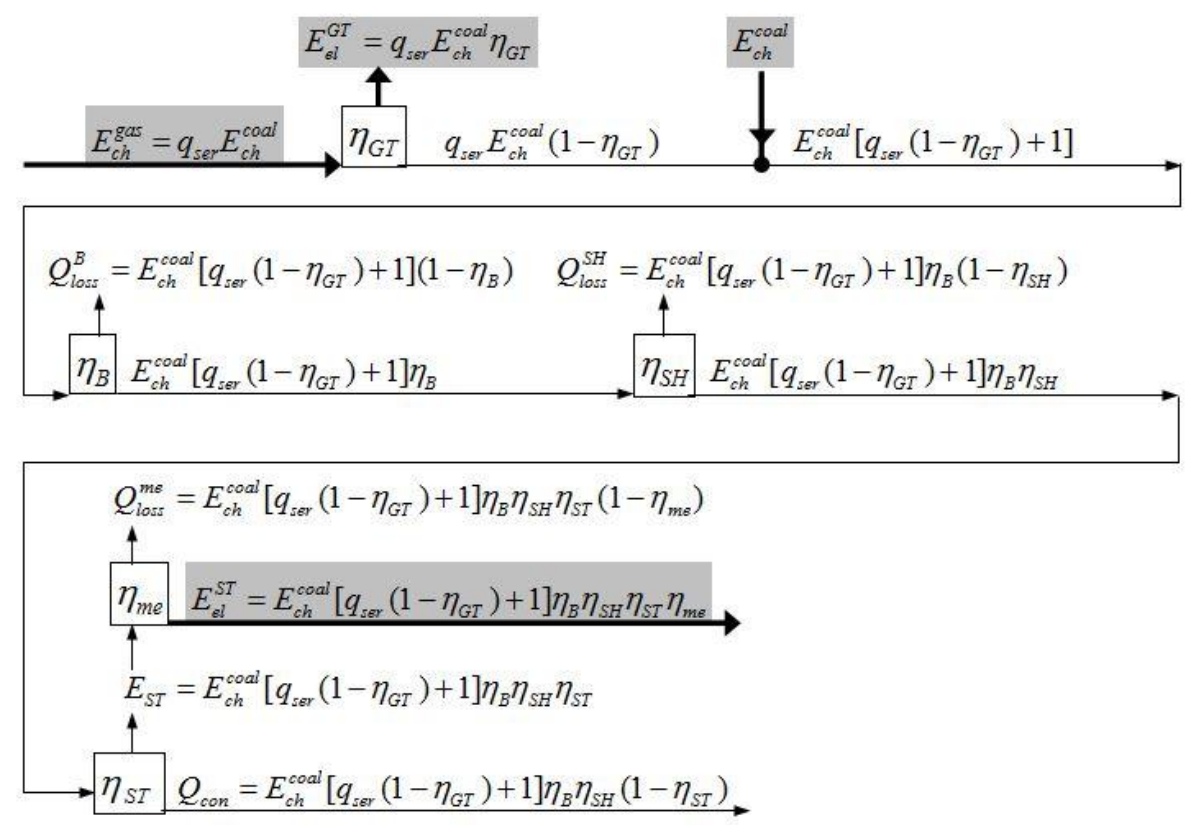

Fig. 4. Energy balance of dual-fuel combined cycle unit with in-series configuration Source: own calculations

The gross efficiency of electric power generation of a dual-fuel combined cycle unit with in-series configuration is expressed by the formula (this efficiency can be as high as $45 \%)$ :

$$
\eta_{e l}=\frac{E_{e l}^{G T}+E_{e l}^{S T}}{E_{c h}^{g a s}+E_{c h}^{c o a l}}=\frac{q_{s e r} \eta_{G T}+\left[q_{s e r}\left(1-\eta_{G T}\right)+1\right] \eta_{B} \eta_{S H} \eta_{S T} \eta_{m e}}{1+q_{s e r}}
$$

\section{where:}

$E_{c h}^{g a s}$ - chemical energy of gas combustion in the gas turbine,

$E_{c h}^{c o a l}$ - chemical energy of coal combustion in the boiler,

$E_{e l}^{G T}$ - gross electric output of the gas turbogenerator,

$E_{e l}^{S T}$ - gross electric output of the steam turbogenerator,

$Q_{c o n}$ - condensation heat of the steam of the condenser in the steam turbine,

$g_{\text {par }}$ - ratio of the chemical energy of gas in the energy of the coal in a parallel system, 
$q_{\text {ser }}$ - ratio of the chemical energy of gas in the energy of the coal in a series system, $\eta_{B}$ - gross boiler efficiency (for the case of the nuclear power plant- efficiency of the reactor and steam generator),

$\eta_{H R S G}-$ gross efficiency of the heat recovery steam generator,

$\eta_{S H}-$ energy efficiency of the crossoverpipe used to feed steam into the turbine,

$\eta_{G T}-$ gross efficiency of the gas turbine,

$\eta_{S T}=\eta_{C R} \eta_{i}-$ energy efficiency of the steam turbine (product of the efficiency of Clausius-Rankine cycle and internal efficiency of the steam turbine),

$\eta_{m e}=\eta_{m} \eta_{G}-$ electromechanical efficiency of the steam turbogenerator (product of the mechanical efficiency of the steam turbine and total efficiency of the generator).

Table 1. Summary of basic input data for calculations of specific cost of power generation in the analyzed technologies

\begin{tabular}{|c|c|c|c|c|c|c|c|c|c|}
\hline Power plant type & $\begin{array}{l}\text { coal-fired } \\
\text { with air } \\
\text { combustion }\end{array}$ & \begin{tabular}{|l|} 
coal- \\
fired \\
with oxy \\
combust \\
ion \\
\end{tabular} & nuclear & photovoltaic & $\begin{array}{l}\text { prosumer } \\
\text { photovoltaic }\end{array}$ & wind & $\begin{array}{l}\text { prosumer } \\
\text { wind }\end{array}$ & $\begin{array}{c}\text { combined cycle } \\
\text { (CCPP) }\end{array}$ & $\begin{array}{c}\text { dual-fuel } \\
\text { combined } \\
\text { cycle (DFCC) }\end{array}$ \\
\hline $\begin{array}{l}\text { Estimated investment } i \text {, mln } \\
\text { PLN/MW }\end{array}$ & 6,5 & 9.1 & 18 & $\begin{array}{c}6.3 \\
(1.5 \mathrm{euro} / \mathrm{W})\end{array}$ & $\begin{array}{c}12.6 \\
(3 \text { euro/W) }\end{array}$ & $\begin{array}{c}6.3 \\
(1.5 \mathrm{euro} / \mathrm{W})\end{array}$ & $\begin{array}{c}12.6 \\
(3 \mathrm{euro} / \mathrm{W})\end{array}$ & 2.7 & 4.6 \\
\hline Annual operating time $t_{R}, h /$ year & 7500 & 7500 & 8000 & 750 & 750 & 1750 & 1750 & 7500 & 7500 \\
\hline Internal electrical load: $\varepsilon_{\mathrm{el}} \%$ & 7.6 & 33 & 7.6 & 1 & 1 & 1 & 1 & 4 & 6.2 \\
\hline Construction period b, years & 5 & 5 & 5 & 1 & 1 & 1 & 1 & 2 & 5 \\
\hline Specific fuel price, PLN/GJ & 11.4 & 11.4 & 6.6 & 0 & 0 & 0 & 0 & 32 & $\begin{array}{c}\text { coal }=11.4 \\
\text { gas }=32\end{array}$ \\
\hline \multicolumn{10}{|l|}{ Exploitation period: $\mathrm{T}=20$ years } \\
\hline \multicolumn{10}{|c|}{ Annual rate of maintenance and overhaul $\delta_{\text {serv }}=3 \%$. } \\
\hline \multicolumn{10}{|c|}{ Coefficients: $x_{\text {sal,t,ins }}=0.25 ; x_{s w, m, w a s}=0.02$. } \\
\hline \multicolumn{10}{|c|}{ Discount rate $r=8 \%$} \\
\hline \multicolumn{10}{|c|}{$\mathrm{CO}_{2}$ emission charges: $\mathrm{e}_{\mathrm{CO} 2}=29.4 \mathrm{PLN} / \mathrm{Mg}_{\mathrm{CO} 2},\left(\mathrm{e}_{\mathrm{CO} 2}=7\right.$ euro; exchange rate EURO/PLN=4.2). } \\
\hline \multicolumn{10}{|c|}{ Tariff charges on emissions: $p_{\mathrm{CO} 2}=0,29 \mathrm{PLN} / \mathrm{Mg}_{\mathrm{CO} 2}, p_{\mathrm{CO}}=110 \mathrm{PLN} / \mathrm{Mg}_{\mathrm{CO}}, p_{\mathrm{NO}}=530 \mathrm{PLN} / \mathrm{Mg}_{\mathrm{NO} x} p_{\mathrm{SO} 2}=530 \mathrm{PLN} / \mathrm{Mg}_{\mathrm{SO} 2}, p_{\text {dust }}=350 \mathrm{PLN} / \mathrm{Mg}_{\text {dust }}$} \\
\hline \multicolumn{10}{|c|}{ Emission from coal combustion: $\rho_{\mathrm{CO}_{2}}=95 \mathrm{~kg} / \mathrm{GJ}, \rho_{\mathrm{CO}}=0,01 \mathrm{~kg} / \mathrm{GJ}, \rho_{\mathrm{NOx}}=0.164 \mathrm{~kg} / \mathrm{GJ}, \rho_{\mathrm{SO} 2}=0.056 \mathrm{~kg} / \mathrm{GJ}, \rho_{\text {dust }}=0.007 \mathrm{~kg} / \mathrm{GJ}$} \\
\hline \multicolumn{10}{|c|}{ Emission on gas combustion: $\rho_{\mathrm{CO}_{2}}=55 \mathrm{~kg} / \mathrm{GJ}, \rho_{\mathrm{CO}}=0 \mathrm{~kg} / \mathrm{GJ}, \rho_{\mathrm{NO}}=0.02 \mathrm{~kg} / \mathrm{GJ}, \rho_{\mathrm{SO} 2}=0 \mathrm{~kg} / \mathrm{GJ}, \rho_{\text {dust }}=0 \mathrm{~kg} / \mathrm{GJ}$} \\
\hline
\end{tabular}

Source: calculations based on data from Bartnik Ryszard, Bartnik Berenika, Hnydiuk-Stefan Anna. 2016. Optimum Investment Strategy in the Power Industry. New York: Springer and Hnydiuk-Stefan Anna. 2014. Analysis of the parameters of power plants operating in oxy-fuel combustion, Ph.D. thesis. Opole University of Technology. 


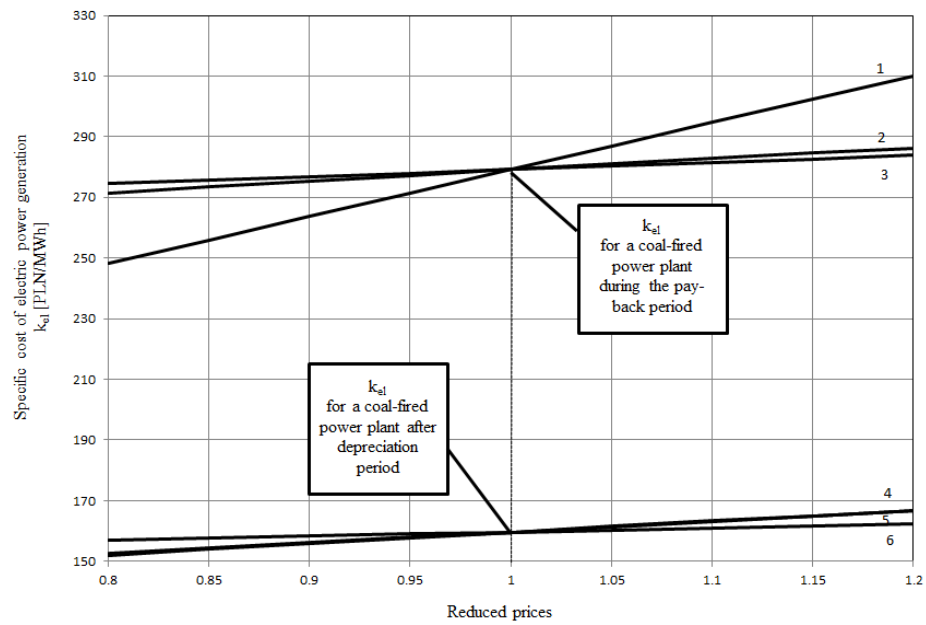

Fig. 5. Impact of fuel prices, internal load of the power plant, and value of investment on the specific cost of electric power generation $k_{e l}$ for a coal-fired power plant during the pay-back period and after this period: 3, 6 - internal electical load of the coal-fired power plant $\varepsilon_{e l}$ during the pay-back period and after depreciation of the unit, respectively; 2, 5 - fuel prices; 1, 4 - investment $J$ in the coal-fired power plant

Source: own calculations

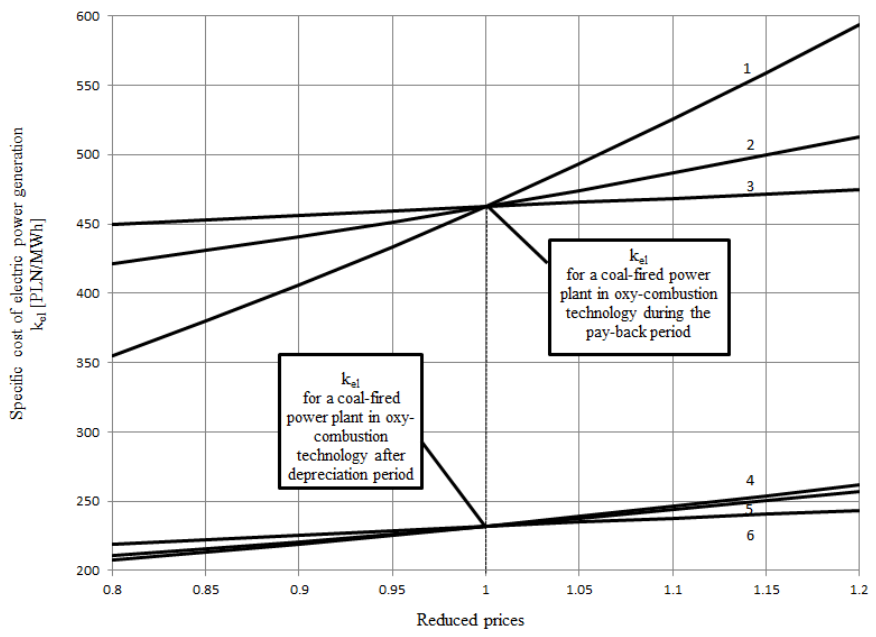

Fig. 6. Impact of fuel prices, internal electric load of a power plant, and value of investment on the specific cost of electric power generation $k_{e l}$ for a coal-fired power plant in oxycombustion technology and for condition that $\mathrm{x}_{\mathrm{ccs}}=0.2$ during the pay-back period and after depreciation period, where: 2,5 -internal electric load of the power plant $\varepsilon_{e l}$ in oxyfuel technology during the pay-back period and after depreciation period; $3,6-$ fuel prices; 1,4 -investment $J$ in the power plant in oxyfuel technology

Source: own calculations 


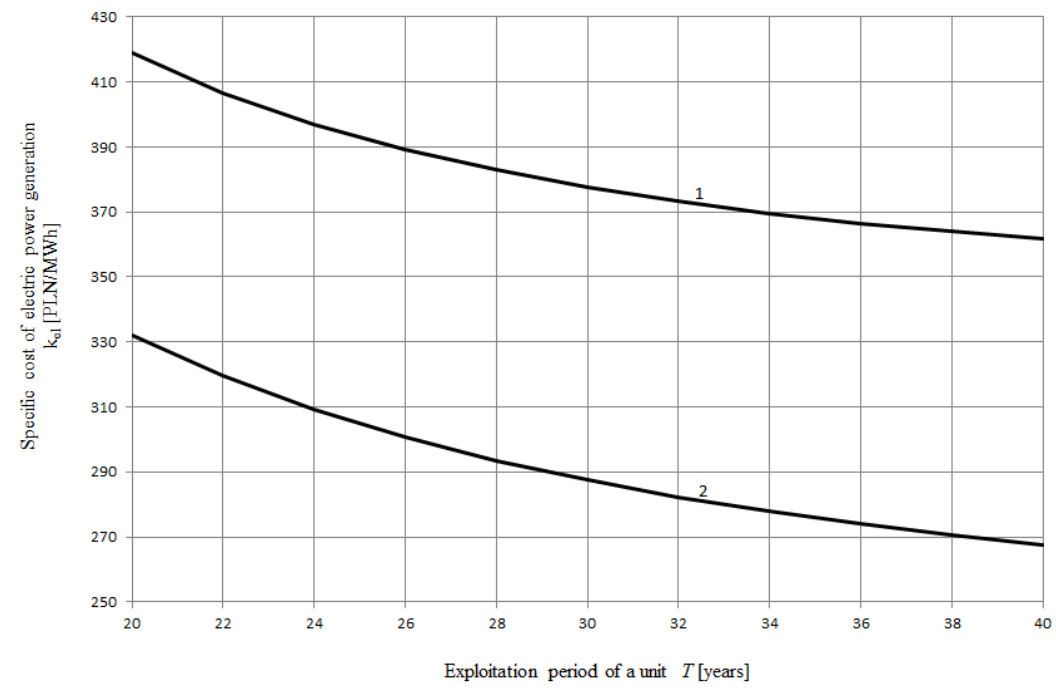

Fig. 7. Specific cost of power generation in a nuclear plant in the function of the exploitation period of a unit $T$ (identical with depreciation period) for the discount rate: $1-\mathrm{r}=$ $8 \%, 2-r=5 \%$

Source: own calculations

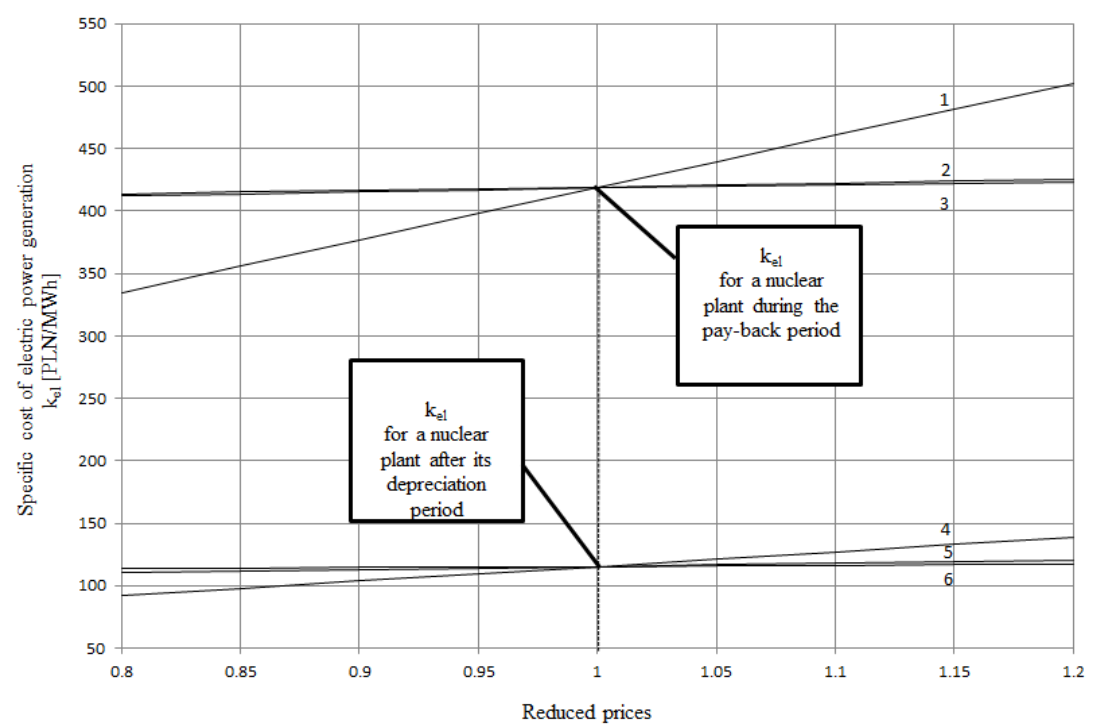

Fig. 8. Impact of fuel prices, internal electrical load of the power plant, and value of investment on the specific cost of power generation $k_{e l}$ for a nuclear plant during the pay-back period and after its depreciation period, where: 3, 6-internal electric load $\varepsilon_{e l}$ of a power nuclear plant during and after its depreciation; 2, 5- fuel prices; $1,4-$ investment $\mathrm{J}$ in a nuclear power plant

Source: own calculations 


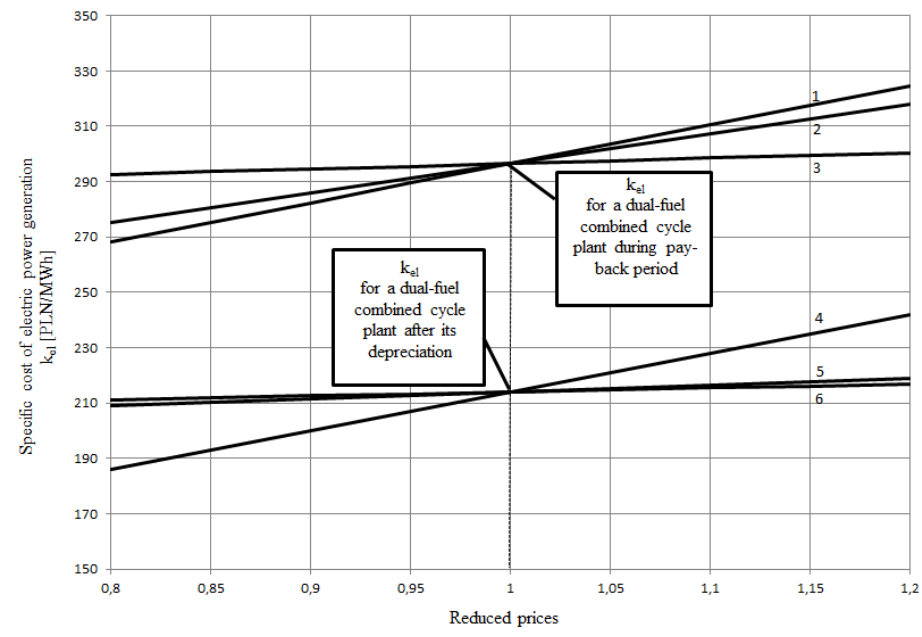

Fig. 9. Impact of fuel prices, internal electric load of a power plant, and value of investment on the specific cost of power generation $k_{e l}$ for a dual-fuel combined cycle plant during pay-back period and after its depreciation, where: 3,6-internal load $\varepsilon_{e l}$ of a dual-fuel combined cycle plant during its depreciation period and after its depreciation, respectively; 4- fuel prices; 2, 5- investment $\mathrm{J}$ in a dual-fuel combined cycle plant

Source: own calculations

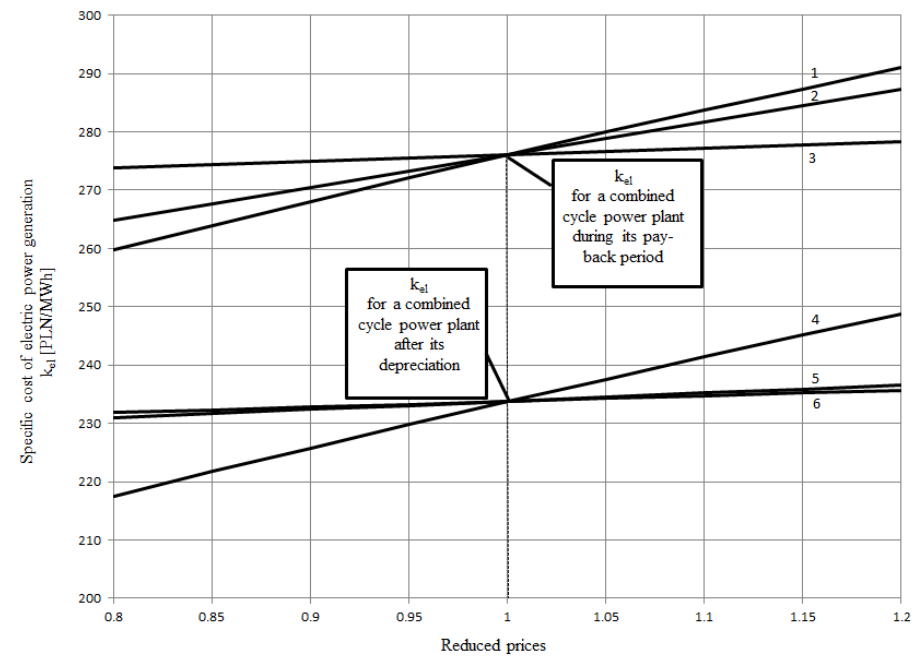

Fig. 10. Impact of fuel prices, internal electric load of the power plant, and the value of investment on the specific cost of electric power generation $k_{e l}$ for a combined cycle power plant during its pay-back period and after its depreciation, where: 3, $6-$ internal electric load $\varepsilon_{e l}$ of the combined cycle power plant during its pay-back period and after its depreciation, respectively; 1, 4- fuel prices; 2, 5-investment $\mathrm{J}$ in a combined cycle power plant.

Source: own calculations 


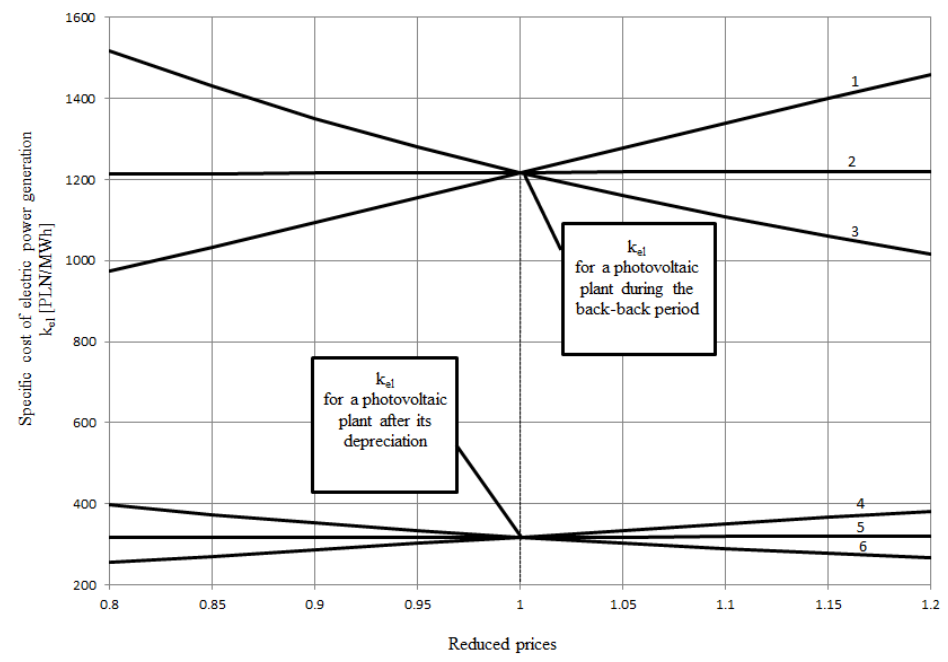

Fig. 11. Impact of fuel prices, internal electric load of the power plant, and the value of investment on the specific cost of electric power generation $k_{e l}$ for a photovoltaic plant during the back-back period and after its depreciation, where: 2, 5-internal electric load $\varepsilon_{e l}$ of the photovoltaic plant during the back-back period and after its depreciation, respectively; 1,4 - investment $\mathrm{J}$ in a photovoltaic plant; 3, 6 - annual operating time of a photovoltaic plant.

Source: own calculations

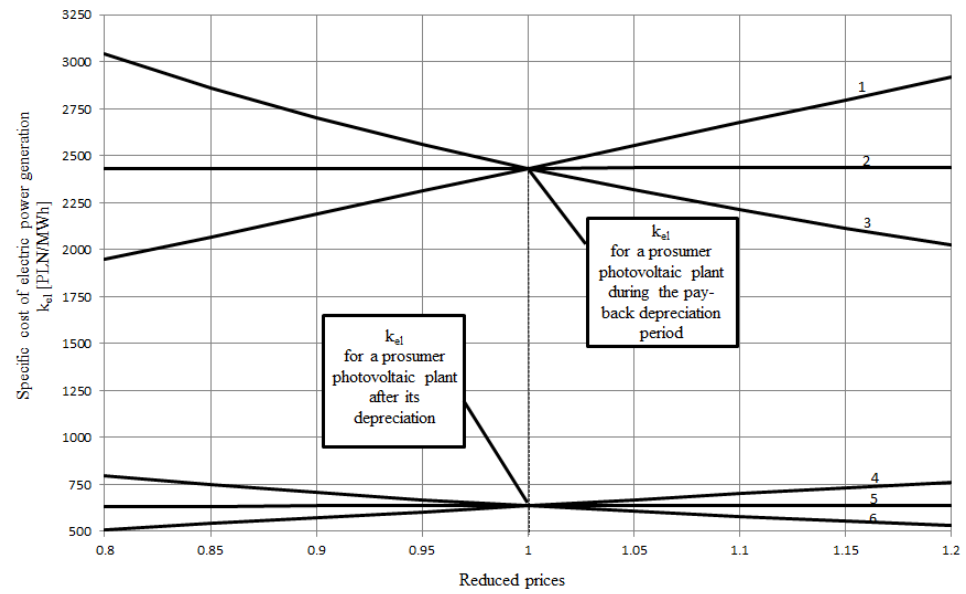

Fig. 12. Impact of fuel prices, internal electric load, and the value of investment on the specific cost of power generation $k_{e l}$ for a prosumer photovoltaic plant during the pay-back depreciation period and after its depreciation, where: 2, 5 - internal electric load $\varepsilon_{e l}$ of a prosumer photovoltaic plant during the pay-back period and after its depreciation, respectively; 1,4 - investment $\mathrm{J}$ in a prosumer photovoltaic plant; 3, 6 - annual operating time of a photovoltaic plant.

Source: own calculations 


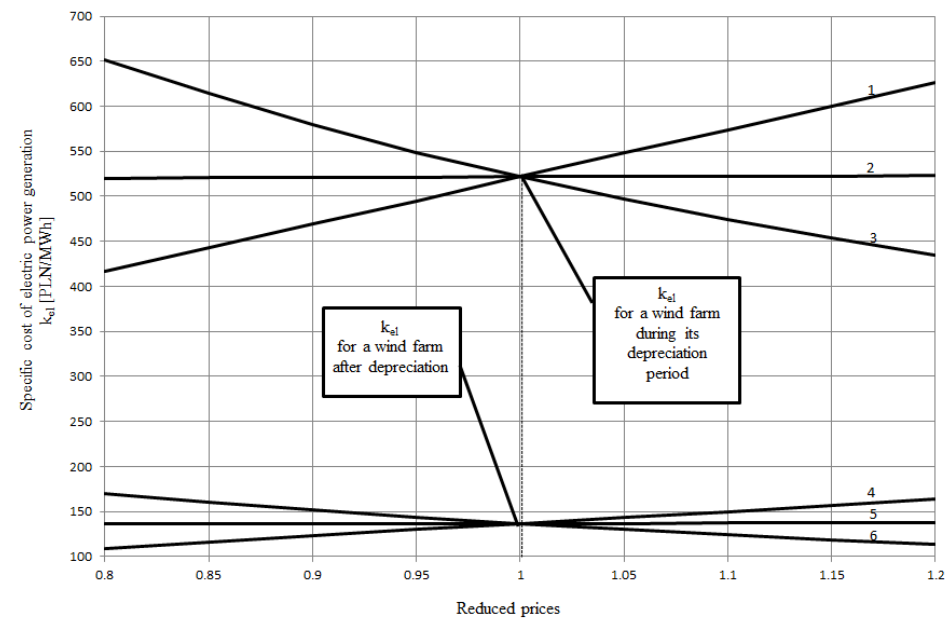

Fig. 13. Impact of fuel prices, internal electric load, and the value of investment on the specific cost of electric power generation $k_{e l}$ for a wind farm during its depreciation period and after depreciation, where: 2, 5 - internal electical load $\varepsilon_{e l}$ of a wind farm during its pay-back period and after its depreciation, respectively; 1,4 -investment $\mathrm{J}$ in a wind farm; 3, 6- annual operating time of a wind farm.

Source: own calculations

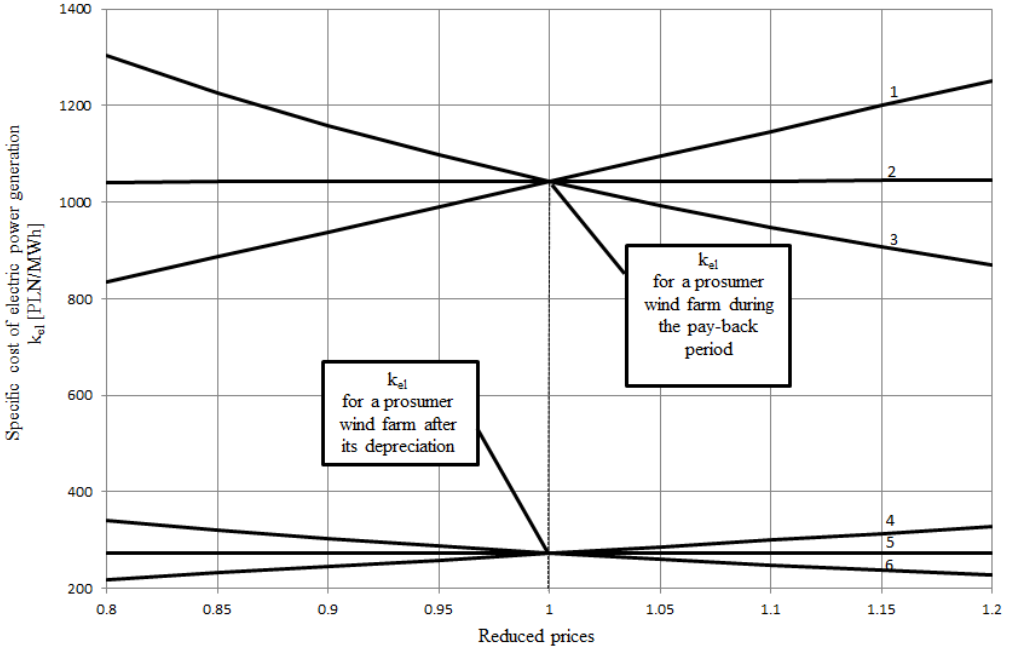

Fig. 14. Impact of fuel prices, internal load, and the value of investment on the specific cost of power generation $k_{e l}$ for a prosumer wind farm during the pay-back period and after its depreciation, where: 2,5-internal electric load $\varepsilon_{e l}$ of a prosumer wind farm during the pay-back period and after its depreciation, respectively; 1, 4-investment $\mathrm{J}$ in a wind farm; 3, 6 - annual operating time of a prosumer wind farm.

Source: own calculations 
Table 2. Summary of mean specific cost of power generation in the particular technologies of its production for the data in Table 1 .

\begin{tabular}{|c|c|c|c|c|c|c|c|c|c|}
\hline Power plant type & nuclear & photovoltaic & $\begin{array}{l}\text { prosumer } \\
\text { photovoltaic }\end{array}$ & wind & $\begin{array}{l}\text { prosumer } \\
\text { wind }\end{array}$ & $\begin{array}{c}\text { dual-fuel } \\
\text { combined } \\
\text { cycle } \\
\text { (DFCC) }\end{array}$ & $\begin{array}{l}\text { combined } \\
\text { cycle } \\
\text { (CCPP) }\end{array}$ & $\begin{array}{l}\text { coal-fired } \\
\text { with air } \\
\text { combustion }\end{array}$ & $\begin{array}{l}\text { coal-fired } \\
\text { with oxy- } \\
\text { combustion } \\
\mathbf{x}_{\text {ccs }}=0.2 \\
\end{array}$ \\
\hline $\begin{array}{l}\text { Specific cost of electric } \\
\text { power generation } k_{\mathrm{el}} \\
\text { [PLN/MWh] }\end{array}$ & 419 & 1217 & 2434 & 522 & 1043 & 296 & 276 & 279 & 463 \\
\hline $\begin{array}{l}\text { Specific cost of electric } \\
\text { power generation after } \\
\text { depreciation period } \\
\mathrm{k}_{\text {el.amort }}[\mathrm{PLN} / \mathrm{MWh}]\end{array}$ & 115 & 318 & 636 & 136 & 273 & 214 & 234 & 160 & 232 \\
\hline
\end{tabular}

Source: calculations based on a formula Bartnik Ryszard, Bartnik Berenika, Hnydiuk-Stefan Anna. 2016. Optimum Investment Strategy in the Power Industry. New York: Springe and data from Table 1.

\section{CONCLUSIONS}

As we can note from the calculations in Fig. 6, the specific cost of electric power generation in coal-fired units employing CCS technology is as much as two times higher from the cost in the power units lacking these technologies (Fig. 5). This cost is even considerably higher than the cost incurred in nuclear power plants (Figs. 7, 8) despite two times more costly specific investment in the nuclear units (computed per unit of capacity). If the policy aimed at limiting greenhouse gases is maintained worldwide, a current issue should concern finding a substitute to the current use of coal. However, if such a policy provides for stricter emissions control, this issue will also concern the use of natural gas. In such a case, there is no other option than the use of fissile fuel. For the case of nuclear power plants, the cost of nuclear fuel accounts for a small proportion (around 5\%) of the specific cost $k_{e l}$ of electricity generation in them, whereas in conventional units the proportion of the cost of coal and gas use are considerable (i.e. around 35\% in conventional coal-fired plants with supercritical parameters, $30 \%$ in the ones employing oxy-fuel combustion and $75 \%$ in combined cycle power plants burning natural gas). In this case, the specific cost of electricity generation in a nuclear plant is equal to around $k_{e l}=420$ PLN/MWh (by increasing the depreciation period from $\mathrm{T}=20$ years to $\mathrm{T}=40$ years, $k_{e l}=$ $362 \mathrm{PLN} / \mathrm{MWh}$; on condition that the interest rate on the investment decreases by $3 \%$, i.e. from $r=8 \%$ to $r=5 \%, k_{e l}=332 \mathrm{PLN} / \mathrm{MWh}$ for T $=20$ years and $k_{e l}=268 \mathrm{PLN} / \mathrm{MWh}$ for T $=40$ years, Fig. 7). The commissioning of nuclear stations additionally lead to the increase in the energy security of the country. In addition, in the long term nuclear-generated power becomes a very cheap source after the depreciation of the units and considerably cheaper from the production in depreciated coal-fired unit with supercritical parameters. This price is decided primarily by the cost of the nuclear fuel, which forms only a few per cent of the specific cost of $k_{e l}$, whereas in the coal-fired units coal accounts for several dozen per cent of the overall cost. Hence, the only sensible and justified way of finding a substitute for coal and gas in the existing power plants is associated with their substitution with fissile fuel. By the way, we can note that the Poland's energy policy needs to combine coal and nuclear sources of power. In this, we need not build new coal-fired plants but retrofit the existing ones so that their operation is possible over the next dozens of years. 
The option of ceasing their operation imposed by the European climate and energy package is counter to the Polish raison d'être. The investment in the retrofitting the existing power plants is inconsiderable in comparison to the investment required to build new ones burning coal. In addition, investment needs to be made in nuclear power plants, as it is justified from the economic perspective. This policy should be accompanied by the development of production of fuel elements for power reactors. The resources of uranium ores in Poland are large. Thus, following this direction offers a rational way of economic and civilization development of the Polish state.

Renewable energy sources (RES) are characterized with particularly high specific costs of electric power generation, as concluded from Figs. 11-14. This is due to the high specific investment needed in them, which is equal to the ones made in the units with supercritical parameters. Another factor is the very short period of their potential yearly operation, which is equal to $1,500-2,000 \mathrm{~h} / \mathrm{a}$ for the wind farms in the conditions of Polish climate (compared to the total number of 8,760 hours in a year). In addition, electricity generation of RES sources is random as a result of unreliable weather conditions. Furthermore, power generation in photovoltaic cells is another solution which cannot secure sufficient power supply in sufficient volumes and in a reliable manner. This is due to their high cost and low reliability, as well as the operating time estimated at 750 hours per year. Hence, despite the fact that solar power is the only endless and reliable source of energy, harnessing its power is matter of remote future, at least dozens if not hundreds of years. A solution which seems to offer a closer perspective is associated with gaining skills in applying fusion reaction. As a consequence of its development, humankind will have an inexhaustible source of clean energy. The existence of RES is only possible due to the subsidies from the state treasury (i.e. it relies on taxpayers). In the old $15 \mathrm{EU}$ member states, power generation in photovoltaics obtains a subsidy in the amount of 430 $€ / \mathrm{MWh}$, while the power from wind turbines $-160 € / \mathrm{MWh}$ ). In addition, such sources can only prove as a supplement to the baseload power plants, which are the only ones capable of continuously supply the required volumes of electric power. Sociological analysis indicates that $80 \%$ of people will live in metropolitan areas in 2050; hence, the idea of the prosumer RES is a complete delusion. Apart from this, the specific cost of power generation in them are the highest, as visible in Figs.12, 14.

\section{REFERENCES}

[1] Bartnik Ryszard, Bartnik Berenika, Hnydiuk-Stefan Anna. 2016. Optimum Investment Strategy in the Power Industry. New York: Springer.

[2] Bartnik Ryszard, Bartnik Berenika. 2014. Economic calculations in power engineering. Warszawa: WNT. [In Polish].

[3] Bartnik Ryszard. 2009. Combined Cycle Power Plants. Thermal and economic effectiveness: Wydawnictwa Naukowo-Techniczne. Warszawa: WNT. (Reprint 2012).

[4] Hnydiuk-Stefan Anna. 2014. Analysis of the parameters of power plants operating in oxy-fuel combustion, Ph.D. thesis. Opole University of Technology. [In Polish].

\section{W JAKIE TECHNOLOGIE ENERGETYCZNE NALEŻY INWESTOWAĆ?}

W artykule przeanalizowano jednostkowe koszty wytwarzania elektryczności w różnych technologiach jej produkcji. Analizie poddano wszystkie dostępne technologie energetyczne (bez elektrowni wodnych): elektrownie węglowe ze spalaniem konwencjonalnym 
i w technologii CCS (Carbon Capture and Storage) oxy-spalania, elektrownie jądrowe, elektrownie gazowo-parowe, elektrownie gazowo-parowe dwupaliwowe, elektrownie wiatrowe, elektrownie fotowoltaiczne. W artykule przyjęto, że najkorzystniejszą ekonomicznie technologią jest ta, dla której średni jednostkowy koszt produkcji energii elektrycznej jest najmniejszy. Zależy on między innymi od takich czynników jak: od jednostkowych nakładów inwestycyjnych, elektrycznych potrzeb własnych, rocznego czasu pracy, ceny paliwa i jej zmian w czasie, udziału energii chemicznej paliwa w całkowitym jego rocznym zużyciu, dla którego nie jest wymagany zakup pozwoleń na emisję $\mathrm{CO}$, taryfowych opłat za korzystanie ze środowiska naturalnego, co wykazano w artykule. W obliczeniach posłużono się ponadto metodyką i uzyskanym za jej pomocą modelem matematycznym jednostkowego kosztu produkcji, co istotne, z czasem ciągłym. Umożliwia on uwzględnianie w obliczeniach m.in. różnych scenariuszy zmian w czasie cen nośników energii. Co więcej, pozwala na wykorzystanie rachunku różniczkowego do analizy wartości jednostkowych kosztów wytwarzania elektryczności. Przeprowadzono ponadto dla rozważanych technologii analizę wrażliwości tych kosztów w celu oceny zmian ich wartości w funkcji zmian parametrów mających na nie wpływ.

Słowa kluczowe: technologie energetyczne, koszt wytwarzania energii, CCS, elektrownie gazowo-parowe, elektrownie gazowo-parowe dwupaliwowe

\section{DOI: 10.7862/rz.2016.mmr.40}

Tekst złożono w redakcji: październik 2016

Przyjęto do druku: grudzień 2016 